\title{
New directions in policy borrowing research
}

\author{
Gita Steiner-Khamsi ${ }^{1}$
}

Received: 21 January 2016/Accepted: 14 June 2016/Published online: 22 June 2016

(C) Education Research Institute, Seoul National University, Seoul, Korea 2016

\begin{abstract}
Research on policy borrowing is a well-established research area of comparative education. Over the past 20 years or so it gained prominence among globalization scholars. Of great interest is not so much the question of which reforms "travel" internationally, and which ones are homebound, but rather why traveling reforms resonate in a given context and at a specific moment, and how they are subsequently translated or locally adapted. In addition to issues of reception and translation, questions on the politics and economics of policy transfer are central to this research area. Empirical studies have shown that borrowing reforms from other countries, from other sectors within a country, or from "international standards" broadly defined often help coalition-building in a country. Policy borrowing also helps to mobilize financial resources, especially when it is preceded by political talk of falling behind some international standards or "best practices." Therefore, the methods of inquiry used, the type of research questions asked, and the conclusions drawn in this body of research tend to address political and economic aspects of educational reform. Arguably, a transnational perspective is indispensable to carry out this kind of intellectual project. The academic preoccupation with policy borrowing has helped to formulate the contours of comparative policy studies. The article provides a brief overview of the main tenets of policy borrowing research and then focuses specifically on three aspects: policy reception, policy projection, and the
\end{abstract}

Gita Steiner-Khamsi

gs174@columbia.edu

1 Teachers College, Columbia University, New York, NY, USA rise of the global education industry as a new actor and beneficiary of global education policy.

Keywords Globalization studies · Policy studies · School reform · Policy borrowing - Global education policy

\section{Policy borrowing research: normative versus analytical questions}

Learning from experiences in other countries is often seen as one of the most salient features of comparative studies. In education, the study of policy borrowing has helped to substantiate and legitimize the field of comparative education. However, learning from comparison does not necessarily mean that policies and practices should actually be transferred from one context to another. In fact, comparativist after comparativist, from Michael Sadler to Brian Holmes to Robert Cowen, warned against analyzing education out of context and against using comparison to transplant educational reforms from one country to another. In practice, however, transnational policy borrowing is the rule and not the exception. For example, Cowen (2000) revisits Sadler's hundred-year-old question: "What can we learn from the study of foreign systems?" He illustrates that, in practice, the comparative study of educational systems has fueled a "cargo-cult," that is, a wholesale export and import of educational models across national boundaries. Skeptical of uncritically transplanting "best practices" from one context to another, I join Cowen and others who prefer to observe, analyze, and interpret policy borrowing and lending rather than engaging in the actual transfer of educational policies.

Nowadays, the research area of policy borrowing has bifurcated in two directions: into a normative and an 
analytical direction. The first group of researchers actively advocates for policy borrowing, and the other group is interested to understand when, why, and how policy borrowing occurs. The first group pursues a normative approach and uses comparison to identify best-performing educational systems from which lessons or "best practices" should be learned and transferred. The second group analyzes why and when such external references are made and examine the impact of such imports on existing policies and power constellations.

Curiously, the membership in both academic camps grew exponentially over the past few years. The group of normative researchers includes the large group of scholars that carries out standardized comparison in order to extract effective system variables that could then be used as indicators for determining global benchmarks. The OECDand IEA-type studies but also other knowledge banks, established by the World Bank and other international organizations, are interested in understanding what works and what does not work. The ultimate goal of applied normative research is to answer policy questions such as, for example, what is the optimal class size, the optimal features of the teacher education system, the optimal teacher salary, the optimal frequency for prescribing student tests, the optimal ratio of public versus private expenditures for education, etc., for effective and high-quality education? In contrast, the group of analytical researchers subscribes to foundational research and opts for comparison as a methodological tool to better theorize the policy process. This second group of researchers has also experienced an unprecedented boom since the turn of the century. Their area of contribution is interchangeably referred to as research on policy borrowing and lending, global education policy, or on educational transfer.

Table 1 summarizes, in an exemplary manner, some of the key differences between a normative and an analytical approach to studying educational transfer.

To be fair, it would be wrong to assume that the two positions-normative and analytical—are mutually exclusive. Many of us are active in both camps: We read, analyze, and produce literature on system variables that impact access and quality of education and that, under certain circumstances and in specific contexts, could be transferred to other educational systems. At the same time, we also operate at a meta-level and reflect on why the act of policy borrowing and lending resonates in specific contexts, who typically advocates for learning from elsewhere, how the imported reform is translated and implemented in a given context, and what impact the act of policy borrowing has on coalition-building among competing policy actors in a given policy context. Most policy borrowing analyses tend to focus on two key stages of policy borrowing are: reception and translation. Reception examines the initial contact with the global education policy at the local level and focuses on the selection process. Translation addresses the local adaptation of the global education policy. In this article, I merely focus on reception studies.

\section{Reception: understanding the "sociologic" of selective policy borrowing}

Typical research questions on reception include why local actors select a particular policy, which problem the borrowed policy supposedly pretends to resolve, or what the "selling points" of the policy are that seem to appeal to local policy actors? In this article, I will delve into some of the key research questions that recent studies on reception tend to examine: When or under which circumstances are educational systems open and receptive to new ideas from elsewhere? How do stakeholders make use of references to international standards to reform their system? What are some of the key features of reforms that went global? Therefore, this article briefly addresses issues that are related to receptiveness, use of international standards, and features of global education policy.

It is necessary to introduce the notion of "externalization" that German sociologist Niklas Luhmann coined and Jürgen Schriewer adopted for comparative studies in education (Luhmann 1990; Schriewer 1990). Embedded in a theoretical framework of system theory (Luhmann 1990), Jürgen Schriewer and his colleagues propose to study the local context in order to understand the "sociologic" (Schriewer and Martinez 2004: 33) of externalization. Schriewer and Martinez find it indicative of the "sociologic" of a system that only specific educational systems

Table 1 Normative versus analytical questions in policy borrowing research

\begin{tabular}{lll}
\hline & Normative & Analytical \\
\hline "Best practice" & $\begin{array}{l}\text { Which are the "best practices" that should be } \\
\text { adopted? }\end{array}$ & Whose practices are considered "best practices"? \\
$\begin{array}{l}\text { Dissemination } \\
\text { How can "best practices" be effectively } \\
\text { disseminated? }\end{array}$ & $\begin{array}{c}\text { Under which conditions is dissemination of a practice likely to } \\
\text { occur? }\end{array}$ \\
$\begin{array}{l}\text { Impact of lesson } \\
\text { drawing }\end{array}$ & $\begin{array}{l}\text { What has been improved as a result of policy } \\
\text { borrowing? }\end{array}$ & Who benefits, who loses in the act of lesson drawing? \\
\hline
\end{tabular}


are used as external sources of authorities. Which systems are used as "reference societies" tells us something about the interrelations of actors within various world-systems. However, the research of Schriewer and most of his associates focuses on historical accounts of global diffusion and reception in education.

I introduced the externalization framework into the field of comparative policy studies. For quite some time now, I have made it my intellectually project to adapt the concept of externalization as an interpretive framework for systematically analyzing policy borrowing and lending in education (Steiner-Khamsi 2004). The group of researchers in comparative education that focuses on the study of policy borrowing and lending has substantially grown, and by now there are, at least, four different generations of policy borrowing/lending researchers each adding new perspectives and research avenues to this fascinating research area of comparative education (see SteinerKhamsi and Waldow 2012).

Arguably, the concept of externalization lends itself as an analytical tool for comparative policy studies as it enables us to understand how "global forces" are sometimes locally induced with the purpose of generating reform on domestic developments (Steiner-Khamsi 2004). I found that it is precisely at a moment of heightened policy contestation that externalization occurs, that is, references to other educational systems, to "international standards in education" broadly defined, or to globalization are made. I concluded that cross-national policy borrowing, discursive or factual, has a certification effect on domestic policy talk. In previous publications, I used the octopus as a metaphor to describe cross-national policy attraction, resonance, and reception. Local actors reach out and grab the arm of the octopus that is closest to their particular policy agenda, and thereby attach (local) meaning to a (global) policy. By default, any study on receptiveness becomes a study on selective policy borrowing. Policy borrowing is never wholesale, but always selective and, by implication, reflects the "sociologic" or context-specific reasons for receptiveness.

In policy studies, John Kingdon coined the term "policy window" to identify favorable conditions for policy change (Kingdon 1995). He found that the convergence of the three following streams is likely to produce change: the problem stream (recognition of a problem), the policy stream (availability of solutions), and the political stream (new developments in the political realm such as, for example, recent change in government). It is important to point out that Kingdon does not take into account processes of transnational policy borrowing. Arguably, in an era of globalization transnational policy borrowing, whether rhetorically or factually, is the norm and not the exception.
Thus, the policy stream tends to be available to politicians and decision makers at all times in the form of "best practices" or "international standards" or lessons learned from other educational systems. In fact, the pressure to borrow is great to the extent that policy analysts are frequently placed in the awkward position of having to retroactively define the local problem that fits the already existing global solution or reform package (see Radtke 2009).

It seems to me that the more challenging task is to bring the flow of the political stream in sync with the other two streams. Framed in terms of a research question, how are different political parties and interests mobilized in support of a change or reform? Research on policy borrowing has much to offer for this research question. As mentioned before, many studies have identified the salutary effect of policy borrowing on political mobilization (see SteinerKhamsi and Waldow 2012). Arguably, borrowing has a salutary effect on protracted policy conflict: It is a coalition builder. It enables opposing advocacy groups to combine resources in support of a third, supposedly more neutral, policy option borrowed from elsewhere. "International standards" have become an increasingly common point of reference in such decisions. The economic dimension, in turn, is particularly salient in developing countries. Economically, policy borrowing is often a transient phenomenon, because it only exists as long as external funding - contingent upon the import of a particular reform package - continues. Policy borrowing in poor countries is to the education sector what structural adjustment, poverty alleviation, and good governance are to the public sector at large: a programmatic conditionality or a condition for receiving aid.

Kingdon's Multiple Streams Framework is valuable for understanding the timing of reforms. However, it is indispensable to adopt a globalization perspective to further refine the framework in ways that suits today's reality of cross-national policy interaction and that takes into account the fact that aid-dependent governments rely on external funding for carrying through educational reforms in their country.

\section{Projections: the functionality of an empty vessel}

The terms "international standards," "twenty-first century skills," and "best practices" greatly resonate with politicians and policy makers, and they resort to them at particular moments of agenda setting: whenever there is a need to generate reform pressure. These terms effectively function as catalysts for change even though there is no agreement what they actually mean. Even better, they serve 
as empty vessels that are, whenever needed, filled with local meaning. Nevertheless, they are politically powerful because they generate fears of falling behind on a global market place and therefore have the potential to build, as mentioned before, coalitions among interest groups that otherwise would be opposing each other. In short, globalization is not an external force, but rather a domestically induced rhetoric that is mobilized at particular moments of protracted policy conflict to generate reform pressure and build policy coalitions.

For borrowing researchers of the first generation, it was vital to interpret the choice of "reference society," that is, the educational system from where policies, practices and ideas were borrowed. Typically, there were cultural, political, or economic reasons that accounted for the borrower's interest in a particular system. Phillips (2004), for example, examined the reasons for the cross-national policy attraction of British government officials and scholars toward the educational system in Germany, during the nineteenth century. The range of motivations for one country to seek inspiration from the educational system of another can be extremely diverse. In the USA political affinity between the Reagan and Thatcher administrations drew the attention of US neoliberal reformers to the UK model in the early 1990s. However, US education policy makers have also been driven by competition (e.g., the Soviet Union the late 1950s and early 1960s) or by curiosity (e.g., Japan during the 1980s).

As with its older cousin Sovietology, Japanology was populist in that it spread, at breathtaking speed, many broad generalizations and stereotypical statements about education in Japan. As Cummings (1989), with reference to an expression coined by Joseph Tobin, has pointed out: American researchers tended to use a "yes, but ..." approach. The approach acknowledges the successes in the other educational system but at the same time "argues that these successes come at too high a price, a price Americans are unwilling to pay" (Cummings 1989: 296). The exaggerated statements or myths about Japanese education included: inverted socialization paradigm (indulgence in early childhood, discipline in adolescence and early adulthood), education for the nation and the state, kyoiku mama (education-oriented mother), rote learning in schools, competition and suicide, elitist higher education, and social inequality. These generalized judgments of Japanese society and education helped to fence off public pressure to learn from Japan. A few years later, the US attraction for the Japanese educational system evaporated as quickly as it emerged due to the economic crisis in Asia. Within a short period of time, the "cautiously acknowledged strengths of Japanese education" (Cummings 1989: 298) disappeared from American accounts. The Japanese educational system fell from grace and American observers started to make extensive use of studies that documented cram schools, student suicide and teacher burnout in Japan. Critics also emerged within the Japanese contexts. In Japan, the crisis talk surfaced at the turn of the new millennium and was used to justify the need for fundamental reform, such as the far-reaching curriculum reform that was implemented in 2002 (Tsuneyoshi 2004).

Unfortunately, contrastive analyses have a well-established place in public discourse. They represent the populist version of comparative policy studies from which academics typically like to distance themselves. During the Cold War, for example, the field of Sovietology did not only satisfy populist demands for understanding why the US nation fell behind in the space and arms race, but it also made it acceptable in educational research to engage in contrastive analyses, that is, in comparison that is primarily directed toward identifying difference. As a result, the two systems were dichotomized, and each was situated at the end of a spectrum. Soviet education was depicted as a system that relied on political indoctrination, whereas the US system supposedly fostered critical thinking in students. The list of binary constructions is long. Suffice it only to mention one more false dichotomy: the Soviet educational system supposedly emphasized access to education at the expense of quality of education. The field of Sovietology was dropped, as some commentators notice (e.g., Foster 1998), virtually overnight and replaced with Japanology. The simplistic methodology was later on adopted in Japanology producing, as mentioned above, a multitude of contrastive studies on US and Japanese education, some of them slightly more sophisticated than others.

Nowadays, the league leaders in international student achievement tests, such as the educational systems of Shanghai, Finland, or Singapore, receive the most attention. A fascinating new body of studies emerged over the last few years that use the method of inquiry that is prototypical for policy borrowing research: an exploration of the local policy context to understand why "externalization" occurs and when the window for transnational policy receptiveness tends to open. This group of researchers examines country-specific or sociologic reasons for explaining the success of the league leaders. German, Japanese, Korean, and US policy analysts, journalists, and academics provide completely different interpretations for why students in Finland performed so well in the PISA studies (Green Saraisky 2015; Takayama 2010; Waldow 2010; Takayama et al. 2013; Waldow et al. 2014). They find that the interpretations have more to do with controversial policy debates in their own country than with actual system variables of the Finnish education system. References to the league leader Finland were used as a quasiexternal source of authority to certify certain, possibly 
controversial reforms in the domestic context. Thus, the "lessons learned" from another educational system always include a significant portion of projection into others' educational system.

More recently, Waldow coined the term "counter-reference" to denote how media accounts in Western countries tend to report on PISA or TIMSS league leaders as deterrents rather than as models for emulation if they happen to be in Asia (2016). Such media accounts feed into the long list of Western stereotypes or prejudices on "Asian education" of why students in Japan, Korea, Shanghai, or Singapore outperform others: harsh discipline, test literacy, and "tiger moms" or "kyoiku mama" (education-oriented mother; see Cummings 1989). That is, they draw mostly on cultural explanations for why students perform well. In other words, it is not the public school system that is high-performing but rather familial values and other, non-school-related factors that account for why Asian students do well in math and science. Waldow's most recent research contributes to a better understanding of contrastive analyses, which tend to propel the "yes, but ..." argument described earlier by Joseph Tobin and William K. Cummings (see Cummings 1989): yes, "their" students (Soviets, Japanese, Chinese, Koreans, etc.) outperform "our" students (in the West), but we are not willing to change our educational values and beliefs in ways that would eventually converge with, or rather what is stereotyped as, Asian education.

Strikingly, these negative stereotypes of Asian education have triggered a wave of critical self-reflection leading to a "pessimistic view that South Koreans hold of heir own education system" (Takayama et al. 2013: 316). One year before PISA 2009, the government had reintroduced national testing (Korean: iljegosa), a measure that was publicly criticized because it would "aggravate excessive competition among students and stimulate the demand for private tutoring" (Takayama et al. 2013: 317). Against this larger public debate, the excellent performance of Korean students in PISA 2009 (rank 2 for reading, rank 4 for math, rank 6 for science) was not celebrated as a victory for the public education system but rather used as a warning to demonstrate the dependency on the education industry, notably private tutoring and private cram schools. In an attempt to appease the critics over excessive national testing, a few incremental changes were introduced over the past few years, such as the Free-Semester Reform in South Korea which is supposed to reduce stress for the duration of one semester when there are no tests issued. Against all international expectations, Korean policy makers refrain from "glorifying" their educational system even though — with a few exceptions - their system ranks top in each and every OECD- and IEA-type student assessment study (Steiner-Khamsi 2003).

\section{Global education policy and the economy of scale}

Naturally, any phenomenon that draws the attention of a great number of observers-such as Finnish successlends itself as a projection screen. Each and every observer explains Finnish success differently, based on their own situated knowledge and, in the case of public policy, "makes meaning" based on their own local policy agenda (see Anderson-Levitt 2012). Similarly, it is the fate of global education policy to become elusive or polyvalent with every new educational system adopting a global education policy.

Scholars at the University of London, Institute of Education, and their associates have convincingly pointed at the changing meaning of global education discourse. Bernstein (1996: 47) asserts that every time a discourse moves, "there is a space in which ideology can play [...]. As this discourse moves, it is ideologically transformed; it is not the same discourse any longer." The transformation of a policy over time is also succinctly summarized in Robert Cowen's brilliant phrase "as it moves, it morphs" (Cowen 2009). Cowen's former doctoral student, finally, Jason Beech has drawn on Bernstein's and Cowen's frameworks to compare the adoption of one and the same global discourse on student-centered learning in the two different policy contexts of Brazil and Argentina over the period 1955-1996 (Beech 2011).

In addition to acknowledging that different actors interpret one and the same phenomenon (e.g., Finnish success in education) or discourse (global discourse on student-centered learning) differently, it is important to also take into account the temporal dimension of global education policy. The temporal dimension, or "life of a policy" (as presented in Fig. 1), matters a great deal and helps predict the likelihood that a reform gets exported or disseminated. The epidemiological model of global dissemination, depicted in

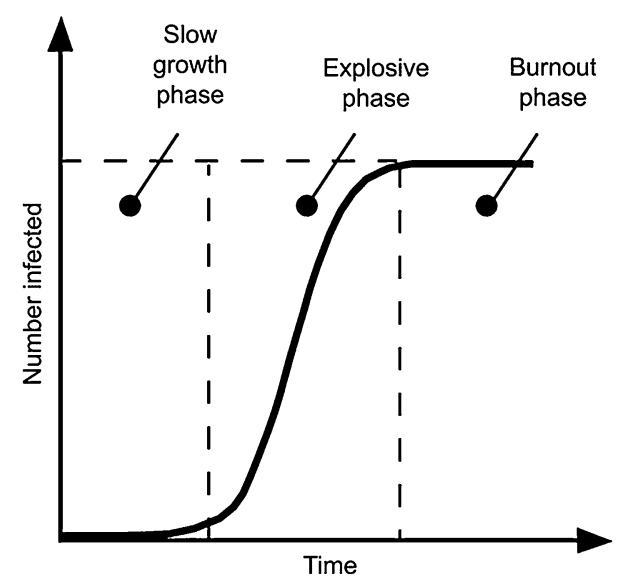

Fig. 1 Lazy-S curve. Source: Watts (2003: 172) 
Fig. 1, is widely used in diffusion of innovation studies and social network analysis (see Watts 2003). The epidemiological model traces the deterritorialization process of a reform over time. It distinguishes between early and late adopters of an innovation. In the early stages, only a few educational systems are "infected" by a particular reform. Adopters make explicit references to lessons learned from other educational systems, especially those that they are specifically seeking to emulate.

A good case in point is the global spread of quality assurance (QA) measures and institutions in higher education. Rattana Lao has produced a fascinating international comparative study on the global diffusion of QA in which she examines in which year higher education systems established formal QA institutions that were separate from ministries of education (Lao 2015). As shown in Fig. 2, her analyses of the higher education literature show that at least 48 countries had adopted QA policies over the period 1983-2010 QA reforms in higher education. The pioneers were the governments of Britain, France, England, New Zealand, and the Netherlands. Starting in the early 1980s, they institutionalized QA by developing distinct policies, putting mechanisms in place, and appointing agencies in charge of QA in higher education. Within the former socialist world system, Poland and the Czech Republic are considered early adopters of quality assessment in higher education. Lao's analysis resembles the lazy-S curve, depicted in Fig. 1, which differentiates between three stages of global reforms: slow growth, exponential growth, burn out. In line with Vidovich (2004), Lao identifies the decade of the 1990s as the exponential growth phase of QA. In the new millennium, the adoption of QA is still occurring but at a slower pace, mostly because the higher education landscape is already saturated with QA reforms.

As outlined in earlier publications (e.g., Steiner-Khamsi 2004), the epidemiological model, which underlies diffusion of innovation research, enables us to explore the deterritorialization process that accompanies globalization in education. With every new education system borrowing a policy from another system, traces of transnational policy borrowing dilute to the point that, during the phase of explosive growth (the middle phase as depicted in Fig. 1), the policy becomes deterritorialized and becomes reframed as an "international standard" or a "best practice," that is everyone's and nobody's reform simultaneously. Even more, once e a critical mass of late adopters has borrowed a particular reform, the geographic and cultural origins vanish, making it easier for decontextualized and deterritorialized versions to spread rapidly. This explains exponential growth during the middle stage, when global dissemination occurs.

\section{The emerging new global actors: the education industry}

It goes without saying that businesses dream of lazy-scurve type of developments, that is, commercial goods or services that at one point take off, go viral and produce
Fig. 2 Global spread of quality assessment reforms in higher education. Source: Lao (2015: xyz)

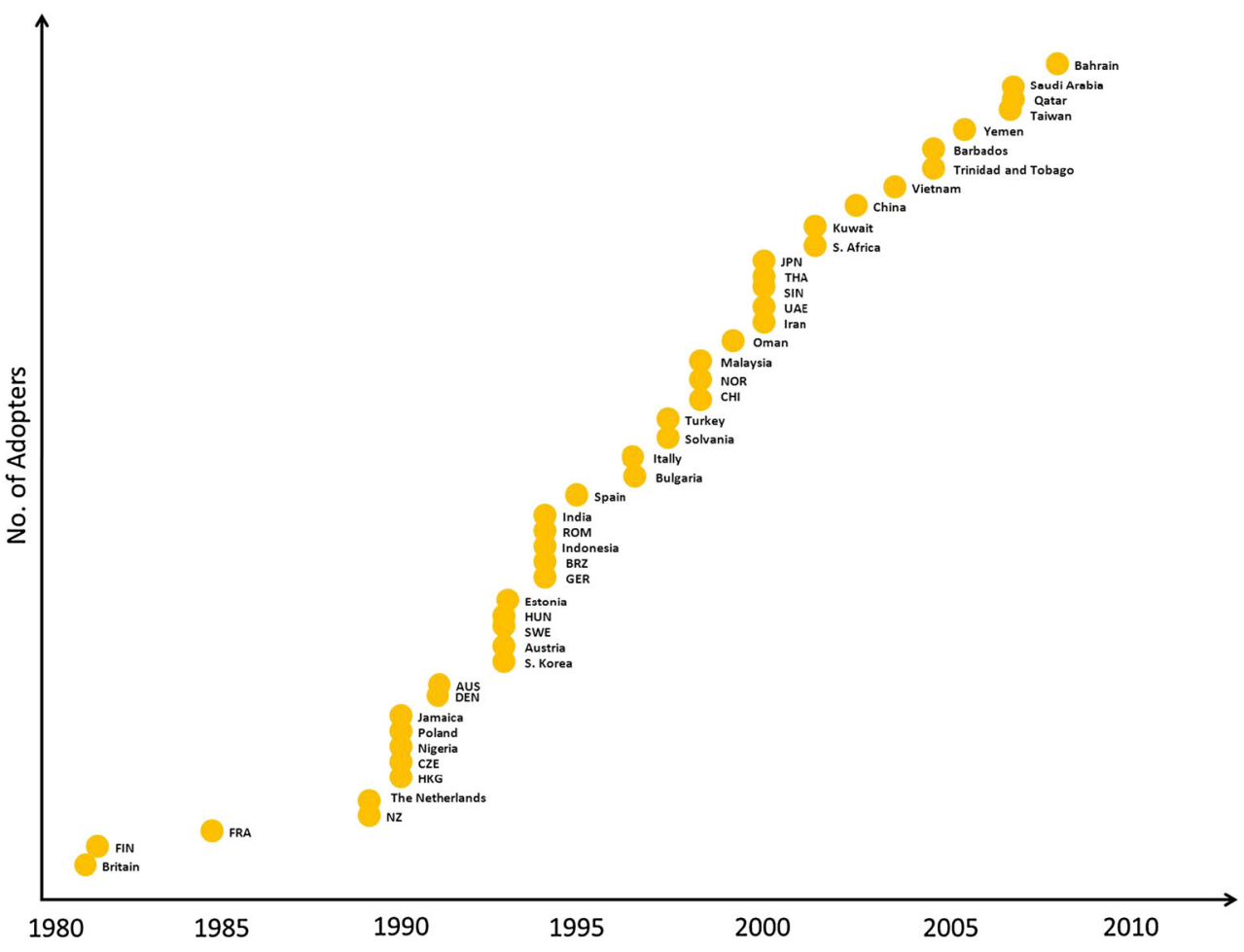


exponential sales. Even though a few private sector providers (technology, testing, and textbook industry) have for decades operated in education, it is only in the past few years that education is considered a global market with an economy of scale (see Ball 2012; Verger et al. 2016). Stephen Ball summarizes succinctly why Pearson, Cambridge Education, Bridge Schools, and many others were able to expand their business transactions globally:

1. organizational changes in public sector institutions (recalibration and "improvement");

2. new state forms and modalities (governance, networks, and performance management);

3. the privatization of the state itself; and

4. the interests of "restless" capital and processes of commodification (public services as a profit opportunity and the provision of "effective" public service provision.

\section{Ball (2012: 94).}

Drawing on the theory of self-referential systems or system theory (Niklas Luhmann), I would like to highlight three interesting phenomena that deserve greater attention: First, the notion of "effective learning" is nowadays used interchangeably with standards-based education reform; second, the power relation between national education systems and transnational organizations and businesses has been revamped benefitting the latter group of actors; and finally, the size of the education system has become massive and continues to grow exponentially over the next few decades. An investigation of these three phenomena would enable us to understand why the global education industry has been able to turn education into a lucrative business. When reading this section, it is important to bear in mind that this article does not address local and national businesses, such as private tutoring or cram schools, but rather companies that operate transnationally.

First, there is clearly a process of continuous rationalization, standardization, or normalization occurring in every sphere of society, described convincingly by various scholars of different theoretical orientation. Standardsbased education reform and "governance by numbers" (Jenny Ozga) are perhaps the two most visible signposts of the standardization process in education. The latter is sometimes referred to as "soft power" because national policy actors have the choice of using, or not using, the results from international rankings to either generate or alleviate reform pressure on aligning their own national system with international norms or best practices. However, they need to communicate and convince the other stakeholders in education in the language of education. Pedagogical language is by default one that puts the learner at center stage, regardless of whether the learner is a child enrolled in preschool, a school-aged student, a university student, or an adult who is trained in non-formal education settings. To push through any kind of standardization in the education sector, policy makers have to make the case that a reform is good for the learner, or even better, improves learning outcomes. The proliferation of tools to measure and compare the quality of education cross-nationally (OECD and IEA-type studies), nationally, within a district, within a school, and also within a class setting is in the education system functionally equivalent to what standardization does to society at large: setting norms. Against this backdrop, the non-state affiliated, private testing industry has become a main arbiter of whether the quality of education or the learning outcomes have improved. In addition, as a result of standardization and outcomes-orientation in education, we are witnessing today at process of backward reform mapping, in which first the tests are determined and afterward the same businesses or organizations (e.g., Pearson, Cambridge Education, International Baccalaureate) produce their own textbooks and teacher education curriculum that match their tests. In effect, this means the creation of parallel education programs or curricula, which, if taken to scale and implemented globally, leads over time to educational systems that differentiate themselves by brand names rather than by nationality. As part of such a doomsday scenario for public education, national educational systems may end up becoming dumping ground for the "rest," that is, the low-income families that do not afford to pay tuition for additional educational services, provided by the global education industry.

Strikingly, some governments in developing countries applaud this kind of alignment within curriculum reform. In fact, alignment is an important selling point for the reform packages of IB, Cambridge Education Services, Pearson and other international education businesses. In Mongolia, for example, scandals occasionally erupt over students who are assessed in high-stakes secondary school exit exams covering content they were never taught. Unsurprisingly, students are lost, parents angry, teachers frustrated, and the general public mistrustful of the government's ability to steer the educational reform process. It is typically in just such a climate that coherent, high-priced reform packages resonate. From the perspective of policy makers, it is better to import an expensive reform package in which all the elements are aligned, than to reinvent everything from scratch, with the support of a myriad of international donors pulling in different directions, each advocating for their own "best practices," and funding their own "international standards." Developing country after developing country faces the challenge of a dysfunctional system (some of which is aid-induced), in which there is little correspondence between what is written in the 
curriculum, what is taught to teachers, what textbooks say, what students learn, and what they are graded and classified in terms of further study.

Second, according to Luhmann's theory of self-referential systems (Luhmann 1990), sub-systems (e.g., the education sub-system) "interact," distance, and differentiate themselves from its so-called environment, that is, from other sub-systems (e.g., politics, economy, religion, family) in an endeavor to preserve their own logic and modes of regulation. Differentiation from other sub-systems is indispensable for its autonomy and own survival. Therefore, actors in the educational system selectively adopt or internalize modes of thinking, arguing, or regulating that are typical of other systems such as, for example, the adoption of quasi-market models from the economic system or the good governance model adopted from the political systems. These examples are meant to illustrate how sub-systems interact, learn from each other, and then reframe what was transferred in terms of their own system logic. From a theory perspective, an interesting phenomenon has surfaced over the past few years: Today, the "others" are not only other sub-systems within a society but also world society, represented by transnational regimes (e.g., OECD, World Bank) who act as global norm setters for national governments (see Luhmann 1997). From a system theory perspective, these transnational regimes represent "environment" for the national education sub-systems. National government therefore engage in "global speak" or discursive policy borrowing to acknowledge the adoption of international standards or global norms. The selective borrowing of international standards is an attempt to survive as a national educational system at a time when international educational credentials are valued more than national degrees. This trend has huge repercussions for national educational systems. In an era of globalization, "global" is likely to become increasingly positively associated with "cosmopolitanism" and "global citizenship" and "national" with backwardness and parochialism. To render the trend even more fascinating: depending on the standing of a national economy within the larger world economy, a private international school leaving certificate (e.g., International Baccalaureate) has a greater value than a certificate from a public national system. As elaborated in another publication, schools that claim to implement "international standards" are on the rise globally. Their main "selling points" are English as a language of instruction, technology integration, and, in some countries, accreditation of the exit examinations by one of the OECD education systems.

Third, the size of the education system has grown tremendously due to the rising middle class in developing countries and beliefs in lifelong learning in OECD countries. Education businesses such as, for example Pearson
LLC, and the media were the first to point out the business opportunities in education. Investors and banks followed suit. For example, the reputable Swiss private bank Julius Baer established a mutual fund or a "global education basket" in October 2014 that consists of stocks of twelve profitable companies. ${ }^{1}$ According to Bank Baer, education constitutes, after healthcare, the second-largest global market, for which they project an annual growth forecast of 7 percent annually. As mentioned before and highlighted by many others, economic growth in developing countries will generate a growing middle class that is able and willing to spend money on the education of their children. Bank Baer predicts that the growing middle class, along with the "high cost of education, is placing a burden on cash-strapped governments, which means increasing dependence on private spending and a growing role of forprofit education companies" (Julius Baer 2014). Low-fee private schools has a long-held tradition in South Asia and Africa, but it is relatively recent that governments, such as the bilateral donors DFID (UK Department for International Development) and USAID (United States Agency for International Development), provide funding for small entrepreneurs and big businesses to establish or manage low-fee private schools with a tuition cost of a few dollars per month.

Today's belief in lifelong learning grants unlimited opportunities for education businesses to sell new courses, certificates, diplomas, and degrees. Even though schools nowadays constitute only one of many educative sites, it is clearly the most lucrative one: the mass of learners stays in school for up to 12 years, is tested periodically in core subjects at critical stages of the education systems, is supplied with textbooks, learning material, and technology/ equipment, is taught by a large number of teachers that undergo teacher education and certification, and is managed by well-paid administrators who both supervise the learner and the teacher. In the wave of neoliberal reforms, governments have systematically commercialized education and provided incentives for businesses to run schools from public funds.

The sheer size of the education system, characterized by long-term contracts for a great number of individual "clients" (up to 12 years in schools), returning customers willing to invest in lifelong learning, the complexity of the value chain (alignment of tests, textbooks, teacher training), and last but not least the opportunity to sell all of the above not only to every student, teacher, and administrator at one school but to hundreds of thousands or millions of

\footnotetext{
1 The twelve companies are TAL Education (China), New Oriental Education (China), Nord Anglia Education (Hong Kong), Kroton Educacional (Brazil), Estácio Participações (Brazil), Pearson (UK), Reed Elsevier (Brazil), 2U (US), Apple (US), Google (US), Apollo Education (US), Grand Canyon Education (US).
} 
schools across the globe must be mind-boggling for business people. Standards-based education, English as the global lingua franca, and the infusion of technology in instruction, and most importantly a business-friendly policy environment account for why we currently experience an epidemiological spread of transnational businesses in education.

\section{Conclusions}

This article has attempted to provide a glimpse into policy borrowing studies and discussed two compelling new directions within this research area: The first direction dealt with studies on "projections" into high-performing educational systems and into international standards. For example, a group of researchers compared how the national media in Australia, Germany, South Korea, USA explain the Finnish success differently, depending on what the hot topics or controversial issues are in the four respective countries (Green, Sung, Takayama, and Waldow). Drawing on system theory (Luhmann), they emphasize the importance of examining the "sociologic" of a context in order to understand the reactions to, and projections into, league leaders.

The second direction, presented in this article, deals with the global spread of reform packages such as, for example, quality assurance in higher education or standards-based education reform in schools. Several scholars have tried to understand the boom in the global education industry (Pearson, Cambridge Education, Bridge, Omega, etc.) and transnational organizations (Teach for All, International Baccalaureate, etc.). Again, system theory may help to draw attention to the "logic" of the current education systems to understand why transnational businesses and organizations have managed to sell or disseminate their goods and services at breathtaking speed across the globe. As proposed in the last section of this article, we need to understand changes in the education system in order to understand why and how the transnational businesses and organizations managed to expand their operation at global scale. In this article, I focus on three features: First, the standardization movement, which permeates all sectors in society, is translated in the education system in terms of "effective learning." Thus, the semantics of standardizations has been pedagogically adapted to reflect the rationale and objectives of the education system. Second, transnational private providers of goods and services in education nowadays compete with national public education. In an era of globalization when transnational student mobility matters, they present themselves as having a comparative advantage vis-à-vis national governments because they are able to open schools with English as a language of instruction regardless of the national language(s) of the country, move away from national curricula to teach "twenty-first century skills," promote cosmopolitanism and global citizenship, and then to top their product with an international seal or an international accreditation. Finally, modern schooling - putting the state in charge of education (and thereby disempowering all other educative sites such as the family, community, church, etc.) and making formal education mandatory for each and every citizen and then eventually resident-led to a well-documented expansion of mass schooling. But the kind of mass schooling that we experience today is a multiple of what modern schooling in the former colonial empires of the global North managed to achieve in terms of size a hundred years ago. Individuals do not go to schools once, but they keep returning to formal education numerous times over their lifespan. Education is no longer only a project of the state, but it is a lifelong project of the soul, making individuals feel fulfilled, empowered, and entitled. For all these reasons, education has become a market with unlimited opportunities for the private sector if the state chooses to deregulate and create business-friendly policies.

The 2016 World Yearbook of Education, entitled The Global Education Industry, assembled a group of noted authors with a critical outlook on the commercialization of education (Verger et al. 2016). Several authors in the book are scholars in comparative policy studies, in particular in policy borrowing research. For researchers in our field, it is incomprehensible how policy analysts could possibly examine educational reforms in one country in isolation from what is happening elsewhere. It is noticeable that businesses think and operate globally. The knot between OECD and Pearson, tied in 2015 for the development of PISA 2018, is a merger between an international governmental organization (OECD) and a global education industry (Pearson). In the neoliberal model, the state is supposed to regulate, set standards, and monitor standards but open up the provision of education to the private sector. The public-private partnership is supposed to be a system of checks and balances, in theory. However, the process of backward curriculum mapping-starting out with revising standardized tests and then reforming textbooks and teacher education - will without any doubt put testing industries at a great advantage not only vis-à-vis other businesses but also vis-à-vis national governments.

What is true for the state also applies to the private sector: Bureaucracy creates bureaucracy by continuously introducing new rules and regulations, by establishing tools to implement and monitor them, and by creating specialized professions that get certified to act on behalf of the bureaucracy. Similarly, businesses grow the sales of their goods and services by continuously creating new needs and new clients, developing new products, and generating 
franchises and other arrangements that enable them to oversee, and benefit from, their expanded market. In comparative policy studies, we have become accustomed to "seeing like a state" in order to explore the policy tools, used by the state, to regulate the education system. The last section of this article proposed that we should now start to "calculate like a business" in order to fully capture, analyze, and interpret why education has become such a lucrative market.

\section{References}

Anderson-Levitt, K. (2012). Complicating the concept of culture. Comparative Education, 48(4), 441-454.

Ball, S. J. (2012). Global Education Inc. New policy networks and the neo-liberal imaginary. London, New York: Routledge.

Beech, J. (2011). Global panaceas, local realities. International agencies and the future of education. Frankfurt: Lang.

Bernstein, B. (1996). Pedagogy, symbolic control and identity: Theory, research, critique. London: Taylor and Francis.

Cowen, R. (2000). Comparing futures or comparing pasts? Comparative Education, 36(3), 333-342.

Cowen, R. (2009). The transfer, translation and transformation of educational processes: And their shape-shifting? Comparative Education, 45(3), 315-327.

Cummings, W. K. (1989). The American perception of Japanese education. Comparative Education, 25(3), 293-302.

Foster, P. (1998). Foreword. In H. J. Noah \& M. A. Eckstein (Eds.), Doing comparative education: Three decades of collaboration (pp. 1-8). Hong Kong: CERC Studies in Comparative Education.

Green Saraisky, N. (2015). The politics of international large-scale assessment: The Programme for International Student Assessment (PISA) and American educational discourse, 2000-2012. UMI dissertations, Columbia University, ProQuest.

Julius Baer, B. (2014). Tracker certificate on the global education basket. Zurich: Julius Baer.

Kingdon, J. (1995). Agendas, alternatives, and public policies (2nd ed.). New York: Longman.

Lao, R. (2015). The culture of borrowing: One hundred years of thailand higher education reforms. London, New York: Routledge.

Luhmann, N. (1990). Essays on self-reference. New York: Columbia University Press.

Luhmann, N. (1997). Globalization or world society: How to conceive of modern society. International Review of Sociology, $7(1), 67-79$.
Phillips, D. (2004). Toward a theory of policy attraction in education. In G. Steiner-Khamsi (Ed.), The global politics of educational borrowing and lending (pp. 54-67). New York: Teachers College Press.

Radtke, F.-O. (2009). Evidenzbasierte Steuerung: Der Aufmarsch der Manager im Erziehungssystem. In R. Tippelt (Ed.), Steuerung durch Indikatoren. Budrich: Leverkusen-Opladen.

Schriewer, J. (1990). The method of comparison and the need for externalization: methodological criteria and sociological concepts. In J. Schriewer \& B. Holmes (Eds.), Theories and methods in comparative education (pp. 3-52). Bern: Lang.

Schriewer, J., \& Martinez, C. (2004). Constructions of internationality in education. In G. Steiner-Khamsi (Ed.), The global politics of educational borrowing and lending (pp. 29-53). New York: Teachers College Press.

Steiner-Khamsi, G. (2003). The Politics of League Tables. Journal of Social Science Education, 1(1), online journal.

Steiner-Khamsi, G. (Ed.). (2004). The global politics of educational borrowing and lending. New York: Teachers College Press.

Steiner-Khamsi, G., \& Waldow, F. (Eds.) (2012). Policy borrowing and lending. World yearbook of education 2012. London, New York: Routledge.

Takayama, K. (2010). Politics of externalization in reflexive times: Reinventing Japanese education reform discourses through "Finnish success". Comparative Education Review, 54(1), $51-75$.

Takayama, K., Waldow, F., \& Sung, Y.-K. (2013). Finland has it all? Examining the media accentuation of 'Finnish Education' in Australia, Germany and South Korea. Research in Comparative and International Education, 8(3), 307-325.

Tsuneyoshi, R. (2004). The new Japanese educational reforms and the achievement "crisis" debate. Educational Policy, 18(2), 364-394.

Verger, A., Lubienski, C., \& Steiner-Khamsi, G. (Eds.). (2016). The global education industry. London, New York: Routledge.

Vidovich, L. (2004). Global-national-local dynamics in policy processes: A case of "quality" policy in higher education. British Journal of Sociology of Education, 25(3), 341-354.

Waldow, F. (2010). Der Traum vom 'skandinavisch schlau Werden'-Drei Thesen zur Rolle Finnlands als Projektionsfläche in der gegenwärtigen Bildungsdebatte. Zeitschrift für Pädagogik, $56(4), 497-511$.

Waldow, F. (2016). Das Ausland als Gegenargument: Fünf Thesen zur Bedeutung nationaler Stereotype und negativer Referenzgesellschaften. Zeitschrift für Pädagogik, 3, 403-421.

Waldow, F., Takayama, K., \& Sung, Y.-K. (2014). Rethinking the pattern of external policy referencing: Media discourses over the "Asian Tigers" PISA success in Australia, Germany and South Korea. Comparative Education Review, 50(3), 302-321.

Watts, D. J. (2003). Six degrees: The science of a connected age. New York: Norton. 